\title{
Self-Control in Islām and its Psychological Aspect
}

\author{
Dr. Farḥat Näz Raḥmān \\ Head, Department of Islämic Studies, Sir Syed University of Engineering and \\ Technology \\ Email: rahmanfarhat@hotmail.com
}

\begin{abstract}
:
The idea of self control is getting captivated more and more by Psychologists but for quite a long time, psychology was inclined more towards the issues and ideas such as, self-esteem, intelligence, happiness etc. No doubt these ideas are important and have value in human life but the missing aspect from all these factors is will power or self-control. The basic teachings of Islam centered on the concept of self-control or in other word self-restraint. This study focuses on the essentials and the benefits of self-control in the light of Qur'än and Sunnah while discussing the psychological aspect of human life in this regard. At a time when the fallout from uncontrolled expenditure and uninhibited consumption is fueling a national malaise, the need of Islämic teachings arises to deliver a comprehensive investigation of the fundamental problem of our time: how to save ourselves from what we want or desire. This strike a chord that while more calories, sex, and intoxicants are easily accessible than ever before, critical social constraints have eroded, constructing a world that deeply tests the confines of human willpower. This study draws a vibrant image of the manysided problem of desire and conveys a blueprint for how one can sensibly stay away from a battle of self-destruction by referring to history, literature, psychology and philosophy of Isläm
\end{abstract}

Keywords: Islām, Self-control, Psychology, Qur'ān, Muslim

\section{Introduction}

Self-control means self-discipline that allows you to stop yourself from doing things you want to do but that might not be in your best interest. How do we react when we see someone fail continuously and constantly, yet others getting success frequently? It is worth nothing but just a matter of holding the limits of our destiny in our hands and when there is no restraint there is obviously a crash. Failure can be defined as 
the lack of self-control, whether it is a failure in terns if dealings or other worldly matters.

In order to practice self-control in everyday life, it is important to build up in one's personality a certain extent of apathy. ${ }^{1}$ One should avoid paying attention or giving importance to every word that is said which brings distress in one's whole being, disturb and upset one's balance and take away one's will power.

Self-control is a feature that is rooted in the creed of Islām and certainly it is not a sheer concurrence. Dose the attribute of self-control is something that Allā'h wants us to strive for?

The pursuit of self-fulfillment in whatever you want is conflicting to the Islāmic teachings; instead Islām emphasizes patience and sacrifice as more noble goals. Self-control, on the other hand, is perfectly Islāmic. The philosophy of contemporary societies is to pursue passionately whatever one desire yet Islām on the other hand stresses on the need to observe restraint, discipline and Sabr (patience).

Islām demands that we need to regulate our actions and speech ever. It is also required to constantly control over our thoughts and feelings. Although there is a negative instinct in human being to opt for, yet we require to control our anger, jealousy; any feelings of pride or arrogance. We are commanded to check our actions against our intentions as we know that the ability to make choices is what separates us from animals.

Allā'h has never said that $\mathrm{He}$ will fulfill human desires and materialize the dreams of human beings by transporting them at the wink of an eye from the prolific soil of the earth to the unproductive plane of the moon. On the other hand Allā'h has endowed human beings with 
intellect and through meticulous study, experiment and observation a human being can determine and understand certain natural laws that allow him to adopt a way that will help to accomplish his objectives and goals i.e the occupation of the universe.

There is another aspect of life of the human being and that is spirituality. If the spiritual laws are observed and acknowledged, they can transport man from his ordinary world to the ecstasy of the heaven. But in order to achieve this state an individual must take an initiative if he has a desire for success, keeping in mind that Allā'h helps those who help themselves. Same as a successful flight operation depends upon the control centre which gives proper directions for its operation, the spiritual flight of a human being relies upon the inner quality i.e. self-control.

\section{Effects of self-control on human psychology}

Early in the 1970s and 1980s self-esteem was considered a powerful key to mental health and successful behavior. But self-esteem eventually disillusioned most of us as its benefits are quite restricted and limited to some extent (Baumeister et al., 2003), so this research would focus on self-control rather than self-esteem. ${ }^{2}$

Self-control has been defined in many ways such as strength of mind, constrain, determination, restraint, self-discipline and will-power. Psychologists on the other hand describe self-control or willpower in more precise ways. According to the majority of psychologists, selfcontrol can be defined as:

- The capability to holdup indulgence, resisting short-term enticement so as to meet long-term objectives.

- The ability to take priority over a superfluous deliberation, emotion or desire. 
- The aptitude to utilize a "cool" cognitive method of deeds instead of "hot" emotional system.

- Cognizant, effortful guideline of the self by the self.

Ascriptions and their related activities might reflect a sort of superficial control that is normally overlooked. One tends to get control by taking the situation into line according to their wishes (principle control) and by bringing themselves into line with surrounding forces (secondary control). ${ }^{3}$ In other words self-control is described as restraint from ones desires and impulses.

To mark the human behavior self-control plays a vital role and is considered an underlying factor. In character building it has a directing influence and therefore it should receive intent development and continuation. Although all powers rest with Allā'h but there is a saying that He helps those who help themselves, so He granted power to man which is within him to raise his character to about infinite heights, so in a way man possesses the master key, evolution and advancement largely depends upon him.

Self-control leads the life to happy mode or in other words moulds the quality of a happy life: one leads a happy life when he is free from the negative attributes like hatred, envy and has his emotions as well as his passions in control. Self-control leads to self-respect as a famous saying goes "respect yourself as no one will respect you if you do not". (Proverb) so in a way self-control attracts respect. Among all the virtues patience is of utmost importance.

"O you who believe! be patient and excel in patience and remain steadfast, and be careful of (your duty to) Allā'h, that you may be successful.." (3: 200) 
Self-control promotes compliance and obedience without which any conviction or belief can make to the true path:

"O you who believe, obey Allā'h and obey the apostle as

well as those in authority from among you (4:59)

Self-control is not to be taken as granted neither it is a gift rather it is an achievement. The secret of success is deliberation and concentration which transmit sturdy desires and intellectual dream into corporal realities. We are the planner of our own souls and Allä'h the supreme is our Guide and Helper.

\section{Self-control in Isläm}

It is a general thought amongst almost all religions and spiritual customs and traditions that human beings should be educated about the manner of self-control. We are a lucky creation of Almighty Allā'h who has gifted us the free will but it is our responsibility to utilize and exercise our free will in appropriate manner. As we expect respect from others to respect our interests and dignity, in the same way we should also practice to respect others interests and dignity to safeguard our own interests and dignity. Hence it is evident here that we cannot go after our wishes and desires and practice whatever we want. There are set limitations from Almighty Allā'h which is beneficial for us.

Self-control and self-discipline leads a human being to selfpurification which in turn purifies our soul and hearts resulting no longer efforts to resist our temptations and to control against lusts and negative desires as a person who is purified desires and wishes nothing except what is moral and ethical for him and others too. We now elaborate as what is the necessity of self-control and self-purification in the teachings of Islām.

The word Taqwa (self -restraint) has been used in the Glorious Qur'ān. ${ }^{4}$ 
On the necessity of self-control, the Glorious Qur'ān says: "And as for him who fears to stand in the presence of his Lord and keeps retraining his soul from evil desires." (79:40 \& 41)

O David! Surely We have appointed you (Our) vicegerent in the earth, so judge between men in justice and follow not vain desire lest it may lead you astray from the Path of Allā'h. Surely those who go astray from the Path of Allā'h, for them is a grievous torment because they forget the Day of Reckoning (38:26) "O you who believe! Be firm in bearing testimony with equity, just for the sake of Allā'h, even if it be against yourselves or against your parents or near relatives (irrespective of the fact that the person concerned), be rich or poor, Allā'h is a greater Well Wisher of both (the parties). So do not be led by the caprice of your soul in doing injustice or deviating from truth. And if you incline or turn away, then verily Allā'h is fully aware of what you do". (4:135)

In these verses we get two types of advice. First and foremost submit Allā'h wholeheartedly, fear Him and obey Him and secondly, to prevent and prohibit our souls from wrongdoings and stay away from those which are harmful. This target can be achieved only when we exercise selfcontrol.

It is a universal fact that self-control begets self- respect. There is wisdom behind Islāmic teachings regarding do's and don't which in long term benefit an individual as well as the society as the whole. When one 
refrains from committing sin, or from extravagance is no need, it provides gratification or in other words one enjoyes inner peace. And once you acquire satisfaction you attains the much needed confidence to reach your true potential. There are three categories of "Nafs" mentioned in the Qur'ān:

1. Nafs 'Ammārā'h (Sürā'h Yūsuf: 53)

2. Nafs Lawwāmā'h (Surā'h Al-Qiyāmā'h: 2)

3. Nafs Mutma'innā'h (Surā'h Fajr: 27-28)

The word "Nafs" used here points to our inner-self. In the Holy Qur'ān the word "Nafs" has been used quite frequent and generally refers to a specific part of our inner self. This part our system contains desires appetite, anger, passion, lust, and ego and to some peoples carnal self or the carnal soul as well. According to the Qur'ānic definition of "Nafs" it is not a part of the soul in fact it is a part of the physical existence. So in reality our body and our "Nafs" are physical part of our system and Almighty Allā'h put has also put in place the spiritual part therein which is the soul (rūh).

In the Qur'ān three adjectives have been used to explain the three different kinds of "Nafs".

1. Nafs-ul-ammārā'h. (The commanding soul) as Qur'ān says:

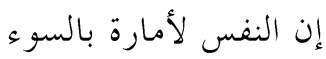

Indeed the Nafs that overwhelmingly commands a person to do sin. [12:53]

This first kind of "Nafs" refers to the dominant part of our system which resides with the senses and is subjugated by worldly desires and passions. This implies that the "Nafs" dominates and command us and tell us as what to do. In other words it governs us telling us to follow it 
commandments. So those possess this kind of "Nafs" they commit sin easily, deliberately, willingly, inexorably, and in any way they want. This concept is overvalued in the west where they actually glorified it by saying that "one should do whatever makes them happy, pleases them or whatever their heart desires." We find such people in every community even among Muslims which means we have a "Nafs"-ul-ammārā'h.

This kind of "Nafs" causes punishment and leads its owner to every evil or wrong action which can be reversed by seeking forgiveness and God's help.

In the early stage of the development and growth of the inner personality, the "Nafs" e ammara remains unrestrained. Childish mischief, laziness, jealousy, quarrels, arguments, stubbornness, bad temper, etc are all part of "Nafs al ammärä'h. In this stage lack of higher knowledge or realization of higher consciousness to Allā'h predominate.

In other words we can say that "Nafs al ammārā'h is the elementary stage of inner self or ego or carnal soul. It continues demanding for pleasure of its low desires, obsessions and for its invariable satisfaction. Hence it is egotistic, selfish and self centered. In "Nafs al ammärä' $h$ ' the intellect is at its lowest ebb and has no part to play. Therefore it requires canon law, the Shariat, to regulate the "Nafs al ammära ' 'h' in order to bring it to higher levels of consciousness, so that it is brought within the limits ordained by Allā'h (Hūdūdulla'h). The 'Nafs al ammārä'h' or carnal soul is required to be awaken which prick the conscience of the man and hence to enable him to live in peace and contentment and to be a high-quality citizen. For accomplishing goodness, for attaining moral fear, for achieving good behavior and for self 
realization; 'Nafs al ammārā'h is required to be kept under constant watch and control.

We can find the numerous verses in the Holy Qur'ân regarding the existence of this kind of Nafs. This type of Nafs is in the commanding position to lead one to commit wrongdoing. It is lower in animals as they operate according to the demands of nature. Take the example of a lion or tiger when they gulp down another creature it is because of their requirement but not for greed and once the animal's requirement is fulfilled it does not track other animal, whereas on the other hand a man is greedy to the extent of gulping down the whole world and still his hunger does not fulfilled. Man's appetite is never satisfied. There are several examples from the history of factual description which depict the existence of Ammärä'h. One of them was the late Shah of Iran; the more he destroy the humanity the more he became thirstier and similarly the more he stole, his greediness increased. Shaikh Sā'di, the renowned Iranian man-of-letters narrates the tale of Mahmood Shäh Ghaznavī who was on the verge of death but yet death did not overtake him. Finally he ordered that all his royal ornaments and jewelry be mounted on mule backs and the convoy of mules be allowed to leave for unknown destination in front of his eyes. As soon as this was done, he died comfortably. To summarize, Nafs al ammāra $\bar{a} h$ is the lowest form of the Nafs and scholars have termed it as mud.

"Nor do I absolve my own self (of blame): the (human) soul is certainly prone to evil, unless my Lord do bestow His Mercy: but surely my Lord is Oft-forgiving, Most Merciful." (Holy Qur’ān 12:53.

2. Nafs-al-lawwämä'h. (The blaming soul/Self accusing soul) 


$$
\text { ولا أقسم بالنفس اللوامة }
$$

"And I do call to witness the Nafs that blames"(75:2)

Lawwāma' 'h is derived from Lom which means to reproach. This Nafs refers to the awareness or consciousness from its own deficiency or imperfection.

In this the Nafs reaches the stage where if one commits a sin its conscience awakens and pricks the person who commits it. This is the first sign that man's Nafs is well awake and maybe a good number of men around the world are at this stage. If a man commits a sin, his Nafs awakens him and in the result he repents and feels sorry for what he has done. It is due to this self-appraisal which forces some criminals to give up their evil ways.

Nay! I vow by the self- critical soul. (Holy Qur'ān 75:2)

lawwäma' $h$ here means to self-cause of guilt, to self-scolding and accusation of self. Hence this kind of Nafs sometimes tempts a person to commit a sin he then itself blame, feels guilty and ultimately the feeling of guilt increases so much that the person repents and gives up the sin. In other words that the person who commits a sin, his/her conscience pricks and they wish they could reverse it or they regret for having done it and they even make a firm determination not to repeat it again in their life, so in a way they battle their Nafs and in this struggle they sometime commit blunders but they try their level best to stay away from sin.

According to Freud's psychoanalytical theory of personality this kind of experience can be defined in terms of ego and superego identity in which an individual reviews his actions and goes through the process of rejection and acceptance i.e. the rejection of bad deeds and acceptation of good deeds. The position of the ego here is like the haram regulator of 
good and bad deeds. It makes a decision how to fulfill each desire and in what manner. While the superego judges the moral and ethical aspect of the personality of an individual resulting in the right actions irrespective of the consequences and reality. The ego on the other hand is one which only decides as what to be done with a desire. Hence the Nafs-allawwäma'th is a level of conflict and stage of decisions in which the good acts supersede or win most of the time.

At this stage, the Nafs is also referred to as the soul that blames, as is mentioned in the Qur'ān in the following verse:

"And I swear by the reproaching soul [to the certainty of resurrection]." (Sürah Al-Qiyämā'h 75:2)

\section{Nafs-al-muțainnā'h (The Peaceful Soul)}

$$
\text { يأيتها النفس المطمئنة، إرجعي إلى ربك راضية مرضية }
$$

"To the righteous it will be said "O peaceful soul, return to your Lord well pleased, and pleasing to Him" [89:27-28]

Here the Almighty Allā'h addresses the mutmain Nafs (the soul at peace). In this context the mutmain stands for two things.

1) They are at peace as they are contented with the command of Allā'h, so there is nothing else in the world that makes them happy or pleases them except what pleases Allā'h. In other words they submitted their will according to the will of Allā'h. This kind of Nafs is tranquil as it rests on the certitude of Almighty Allā'h.

2) Secondly they reach at the state of serenity. It possesses no unlawful desires. Though it has desires but this kind of Nafs desires only good things. Hence they desires only those things or act which Allā'h views as pleasing and refrain desiring those things that Allā'h has marked undesirable. 
As a Muslim we have the prime example of self-control in the personality of our beloved Prophet Muhammad (SAW). Self-control governed every word, act, and practices of the Holy Prophet Muhammad (May peace be on him). He was never seen deviating from his path of duty and apply the supreme tolerance and patience no matter how hard or severe the situation was. He was the role model to be followed and all the qualities of the perfect human beings were embodied in him. The noble virtues of Islām such as patience, mercy, honesty, sincerity, courage, justice so on so forth were carried by him. He was undeniably - as Hazrat Ayishā declared a personification of the divine Book the Qur'ān.

\section{Example of Self-Control from the history of Islām}

The reason why Islām has spread across the globe as the fastest growing religion is the teachings of self-control and patience. These two qualities of patience and tolerance are the main and real virtues which can lead towards the harmony within the communities in particular and the whole world in general. ${ }^{5}$

It reminds me the narrative from the companion and the cousin of the Prophet Muhammad (SAW). In the battle of Khandaq (ditch) Hazrat Ali (AS) confronted a warrior who enjoyed great reputation his people. The Muslims defended themselves against an attack on Madina. The warrior was famous as a fierce fighter and no one dare to confront him. Hazrat Ali (SA) challenged him and the fight continued until Ali threw him down on the ground after fierce fighting and sat on his chest in order to control him completely and when he was about to kill him, the warrior spat on Hazrat Ali (SA) face. People around were certain that the nonbeliever had no chance of his survival as that insult amounted to inviting his death but to their surprise Hazrat Ali (SA) walked away from him 
without hurting him. Upon a query that why he had spared his life, Hazrat Ali (SA) replied "If he had killed him then it would have been considered a revenge in order to satisfy his anger rather than for the sake of Allā'h, so he set him free." Hearing this the guy embraced Islām on the spot.

There is a lesson in this story that we should work for self-analysis and accountability of ourselves whether we are able to control our anger and keep calm in such a situation. We need to check our intentions which are affected by ego and became a source of self-satisfaction instead of serving the cause of Allā'h.

Similarly there are various other distractions around us which divert our attention from the true path, such as the love for money or being materialist and lust for luxury and comfortable life or even the love for our family and kids.

I have observed many good scholars and very religious minded practicing Muslims who cannot teach values to their own family members as they are of the opinion that their love for their children is so much that they avoid telling them something which is not acceptable to them. In Islām there is no scope for personal feelings to come in the way of Allā'h. The teachings of Allā'h are very clear in this regard as we cannot inherit Taqwa (values of tolerance and patience). We need to train ourselves by practicing these things or we end up with extremism, violence and superstitions culture.

Fasting, an obligatory ritual in Islām provides a best example of self-control. Due to fasting the rigid habits or overindulgence are overcome. The soul is let free form the carnal desires. The restrictions and obligations to refrain from not only by eating and drinking but also exercise control over the tongue, eye, ears, heart and other limbs. Side by 
side with the control over physical appetite, we require to control our negative actions and emotions.

The Messenger of Islām, Muhammad (peace be upon him) said that: "If anyone abuses you verbally, behave rudely towards you, or even go to extent to hurt you, then your response should be "I am fasting; I am really fasting." (Al-Bukhari and Muslim). ${ }^{6}$

\section{Discussion:}

Islām laid great emphasis on the importance of self-defence. Allā'h specifically ordained in the Qur'ān addressing His believers to build Taqwa, meaning self-discipline. Taqwa in the broader sense covers self-control, self-discipline, self-education, self-patience and self-restraint. Believers are ordained to treat their enemies with respect and be patient with them, then surely they will revisit their negative approach and choose to adopt better ways.

An additional feature of the Muslim community is their emphasis on morality. In Islām the Muslim character rests on morality. There are detailed description of actions which are considered immoral in the Qur'ān such as cheating, dishonesty, lie, envy, insulting others, backbiting, disloyalty, breaking promises, breaching the trust, disobeying parents etc are all stated clearly and categorized as evil.

There is a famous hadith of our beloved Prophet (SAW): "The great Jihāad (struggle) is the Jihad (struggle) with Nafs (Self)."

Another negative attribute is anger as most horrific and heinous crimes and acts are committed in a state of anger. Prophet Muhammad (SAW) has advised on several occasions that do not get angry as it is a destructive force and does not see who is affected or what is destroyed. Alla' 'h (SWT) has given us the key to self-control in the Qur'än: 
The spiritual aspect of Islämic life commence with Riyādat alNafs (a battle against ego) as the lower self has a capacity or tendency to draw human being towards arrogance and vices. To attain Allā'h's proximity a sincere worshipper should have a powerful effort of will in order that the purity of soul is achieved.

Riyāda in Arabic means "training" or "disciplining". It was used by the Arabs in relation to horse training. In Sufism this term refers to riyādāt an Nafs i.e. disciplining the soul/training the ego. There is a famous Arabic proverb that says:

"The purpose of sports (Riyāda) is not to win cups, but to discipline the soul."

It is evident that whenever we are surrounded ourselves by people or stay close to them we will be influenced by them and will adopt some of their characteristics.

Shams al-Tabrīzī (R.A.) says,

"Without doubt, whenever you sit with someone and are with him, you will take on his disposition. Whatever you gaze on will certainly affect you in some way. If you look at green herbs and flowers, freshness will come. The sitting companion pulls you into his own world. The best example to quote here the recitation of the Qur'ān which purifies the heart, because you remember the prophets and their situations."

Religion of Islām is based on the teachings of universal values beginning with the prayers of five times, intended to teach discipline in our life. It offers a complete code of life. Fasting in Ramadan is meant to learn and train ourselves in attaining self-control and pilgrimage to Mecca teaches us resilience in order to defy temptation. We are commanded to lower our gazes subjected to strict injunctions about examining the 
sources of the income and duty bound to regulate what we earn or consume. We are demanded to control our speech when talking to others.

As a Muslim we even have to restrain from the display of our anger even on the battle field and fight honorably and ethically. The philosophy of modern societies is to follow with passion whatever one desire. While on the other hand Islām lays an emphasis on discipline, moderation, self-control and Șabr (patience).

The Qur'ān even goes as far as to say: "Who is more astray than the one who follows his own lusts?" (28:50). The inference here is that an individual who controls his desires, represents the excellence of right path, hence the secret of success is in self-control and discipline as taught by the Qur'ān and Hadith (sayings of the Prophet). It is a widely accepted option that the ability to make choices and take decisions is what distinguishes us from animals. Similarly the ability to self-regulate is what separate us from the truly less remarkable. To sum up Allā'h Almighty through His commands and injunctions guided us to attain the kind of discipline through various acts of worship and rituals which ultimately lead us to success.

The description of the two chapters of " The Revival of the Religious Sciences (Ihȳa 'Ūlūm al-Dìn)" classify saintly and spiritual procedures adopted by orthodox Islām. On Disciplining the Soul, which refers profuse tales from the Islāmic literatures and life of the Imām Ghazālì in his book "on discipline the soul" elucidate how to obtain qualities of good character an cure the diseased heart. This book contains fascinating tales from Islāmic literature and lives of the Sufis. In breaking the two desires “ he illuminates greediness and carnal desire and concludes that the 
adoption of middle path in all affairs is the best option as desired by the holy prophet (SAW). ${ }^{7}$

A precise and conclusive way to sum up our discussion on Islām and self-control would better be found in the sayings of the holy prophet (SAW), who says:

"The conducts most treasured by Allā'h (are those) done on a regular basis, though they are few in numbers." 8

It tells volumes of the importance of minor endeavors on the part of the believers os Almighty Allā'h gives great weightage to them.

In his book Jihād-un-Nafs, Imām Ghazāli refers to the holy prophet (SAW) saying:

"There are two impulses in the soul, one from an angel which calls towards good and confirms truth; whoever finds this let him know it is from God and praise Him. Another impulse comes from the enemy which leads to doubt and denies truth and forbids good; whoever finds this, let him seek refuge in God from the accursed devil." (Tirmidhì)

\section{Conclusion:}

The major objective of Islāmic religious training is a control of Nafs (the Ego). The great Shaikhs (saints) taught their students through tales and examples draw from parables as how to achieve this in their lives through training.

According to Professor Roy Baumeister, self-control refers to an ability to delay indulgence. But this is not true as it also requires defying short term temptations to achieve the long term goals and the aptitude to 
utilize a cool cognitive structure of attitude rather than a warm emotional way.

Professor Baumeister also says that self-control is tantamount to self-regulation, which means diverse responses comprising foundation of some rule, ideal or values. ${ }^{9}$ As Muslims we believe this principle or value is the way of life called Islām. It has been observed by researchers that self-control has a tendency of breaking specifically at the end of the day after having stressful and challenging days. It has also been observed that most of the diets are broken in the evening and carnal misdeeds and addictive deterioration happen at the end of an extensive and hectic day. Studies reveal that human beings are more inclined to deception and theft when their will power deplete. ${ }^{10}$

In the developed world there is a lack of self-control. For researchers and psychologists it is lacking due to the widely spread notion that self-confidence or self-esteem is the key to success rather than selfcontrol, so generally we concentrate and focus our efforts on developing self-esteem, the idea of being in love with yourself and having a belief in self and consider it a key to success.

Self-control is the root of the teachings of the religion of Islām. We have been given choices and temptations. We have been given injunctions to lower our gaze, to control our anger and calculate our speech before articulation.

The best practical demonstration of the self-control in Islām is in its rituals of worship like, prayers five times a day, fasting and Hajj (pilgrimage). During performing these rituals, which are obligatory, one at every step sacrifices. This is also called self-sacrificing. Self- sacrifice is sacrificing willingly and giving up the things one owns and gives weight 
to and preserving for the sake of his cause by enduring every kind of complexity. It is abstaining from his benefits for the merits he believes in and for the sake of humanity in order to attain the pleasure of Allā'h.

Although human soul is selfish as his own desires and benefits comes first but making sacrifices in order to accomplish Allā'h's blessings by giving up the egoism of the soul is one of the supreme characters among the ideals of the humanity.

Sacrifices lead to the success of our continuous struggle in two ways.

1. They reinforce our inner spiritual and moral resources and build up qualities of character which are necessary to our efforts and struggle at every level.

2. They develop and strengthen consistency and discipline within, providing it the strength and resources to carry out Jihad at the wider social level.

Sacrifices carry importance and are an essential for the progress of all moral qualities, especially for the growth of patience, tolerance, determination, resilience, endurance and fortitude. All these moral attributes can be summed up in just one word i.e. "Șabr". Each and every sacrifice strengthens the quality of Sabr leading it to excellence. In turn the Sabr sustains and raise the capability to sacrifice. 


\section{References \& Endnotes}

1. Significance Of Self-Control, December 24, 2009 retrieved from https: //majesticislam.wordpress.com/2009/12/24/significance-ofself- control/

2. Baumeister, R.F., Campbell, J.D., Krueger, J.I. \& Vohs, K.D, (2003), Does high self-esteem cause better performance Inter personal success, happiness, or healthier lifestyles? Psychological Science in the Public Interest, 4, 1-44.

3 . Rothbaum, Fred; Weisz, John R.; Snyder, Samuel S. Jan 1982, Changing the world and changing the self: A two-process model of perceived control Journal of Personality and Social Psychology, Vol 42(1), 5-37.

4 Mohammad Ali Shomali, (2013) http:// www. aimislam .com/' the- significa nce-of-self-control-and-self-purification/ ' Retrieved December 14, 2018 from the source 'The significance of Self-Con trol and Self-Purification

5 . http://www.themodernreligion.com/basic/charac/self-control.html retrieved from Islam the Modern Religion webpage on October 5, 2018.

6. Yuksel A.Aslandogan.(Oct 2008) Fasting in Ramadan and Developing Self-Control by Retrieved from http://www. onislam. net/english/reading-islam/understanding-islam/worship/fasting,

7. Al-Ghazali on Disciplining the Soul and on Breaking the Two 
Desires (The Revival of the Religious Sciences \#22 \& 23) by أب و حامد الـ غز الـي Timothy J. Winter - Abdal Hakim Murad (translator). 1995, Islamic Texts Society, England

8. Saheeh Al-Bukhari, Saheeh Muslim

9. Roy F. Baumeister, Self-control - the moral muscle. February 2012 in the British Psychological Society Journal Volume 25 Part 2. Pages: 112-115.

10 . Mead, N.L., Baumeister, R.F., Gino, F. et al. (2009). Too tired to tell the truth: Self-control resource depletion and dishonesty. Journal of Experimental Social Psychology, 45, 594-597. 